department heads. Each member of this conference represents the group engaged in one particular phase of research, so that in this way a fan-like arrangement results in which all radii converge upon a focal point, the director. This enables the individual investigator to exercise his initiative and ability while at the same time the director is closely connected with each worker and each investigation. One example, with farreaching therapeutic possibilities, that of the discovery of a substance from soil bacilli which inhibited the encapsulation of Friedländer's bacterium and at the same time was highly bactericidal for Grampositive micro-organisms, is given to illustrate the value of co-operation in research. This substance, disco ered by a microbiologist, was at first obtained in crude form; it was passed to the bacteriologists and cytologists to determine its qualities and powers, to the microchemists for analysis, identification and determination of probable composition, to th chemists for fractionation, to the spectroscopists for charasterization, to the cytologists for toxicity, to the microscopists for record of crystalline struction, to the physical chemists for determination of its constants and further study of its structure, and to the surgeons for study of its external effects on badly infected wounds. The Foundation moved, in December 1940, from Philadelphia to new laboratories at Newark, Delaware, which cnntain wings to house such physical aids to research as a cyclotron. These laboratories were planned from the point of view of co-operation and co-ordination of research workers of various phases of chemistry, physics, enzymology, biology, cytology and medicine, so that a united effort may be made along one front for the advancement of science and the benefit of mankind.

\section{Electricity Supply Tariffs}

C. T. Melling, in a paper on "General Factors Affecting the Unification of Electricity Supply Tariffs" read on February 4 before the Institution of Electrical Engineers in London, discusses the general requirements of tariffs, and the fundamental aspects of the demand for electricity. The charge for electricity should be based on service value more than on the cost of supply, but there should be suitable controls to safeguard the individual consumer. The limitations of cost analysis in tariff-building are discussed, and it is pointed out that the need for more information on marginal costs demands more intensive research. The difference in the cost of supply in various undertakings, due to differences in bulk-supply charges and in types of area and load, has an important bearing on tariff unification, and a close examination of the economic and social implications of uniformity of charges throughout Great Britain is desirable before a definite decision is made on this matter. Small supplies to domestic and business premises are discussed in relation to the influence of non-monetary factors, as is also the space-heating load and the need for improvement in the bases of the fixed charges in two-part tariffs. Suggestions are outlined for a uniform system of tariffs, and an appendix to the paper contains an analysis showing the difference in cost of supply between urban and rural areas.

\section{Electrical Aspects of Ferro-Alloy Manufacture}

H. A. Sievering (J. Inst. Elec. Eng., 90, Pt. 2 No. 13 ; February 1943) has discussed the use of, and the power supply to, the submerged-arc electric furnace in connexion with ferro-alloy manufacture. The principal ferro-alloys, the method of grading and their uses are first summarized, and representative electricity consumptions per ton of finished alloy are given. In order to indicate the magnitude of the load, statistical information regarding the quantity of electrically manufactured ferro-alloys is next given over a period of years. This is followed by a description of the type of furnace used, together with brief notes on the electrical equipment and details of the electrodes. In order to indicate the importance of electricity costs, the selling price of typical ferroalloys is given and, for comparison, the proportion of the selling price represented by each tenth of a penny per $\mathrm{kWh}$. It is also pointed out that supplies of raw material are as easily available in Great Britain as they are in the major ferro-alloy producing countries, namely, Norway, Sweden, and the United States.

In order to establish the price at which electricity can be made available, typical costs of production for a $50,000 \mathrm{~kW}$. steam station are given and, on 1939 costs, a price of $\frac{1}{4} d$. per unit is arrived at. A comparison is also drawn with hydro-electric power and it is shown that, for equality of production costs, all other things being equal, the capital expenditure in a hydro-electric station could be as high as $£ 72$ per $\mathrm{kW}$. installed. The disadvantages of a number of private generating stations are obvious, and it is shown that an electricity supply obtained from the Grid is more advantageous. Finally, some typical costs of production for ferro-alloys are given. It is contended that the introduction of a full ferro-alloy industry into Great Britain would offer to the electrical industry a load of some 500 million $\mathrm{kWh}$. per annum, which would require a maximum demand of 75,000 $\mathrm{kW}$. These electricity requirements would have to be made available at a very low price in order that the selling price of the imported alloy should not be exceeded. Employment would not be large as a result of this industry, but the protection which the steel industry would have through the vital ferroalloys being readily available at all times would appear to be sufficient justification for giving careful consideration to the possibility of establishing ferroalloy factories in Great Britain, more particularly when it is borne in mind that the furnace used can be adapted readily at any time to the manufacture of calcium carbide, an equally important raw material which in pre-war days was largely imported.

\section{New Reference Frequency Equipment}

According to V. J. Weber (Bell Lab. Rec., 21, No. 3 ; November 1942) frequencies in radio and carrier telephone are now held constant to a very high degree of precision, and for the manufacture of radio and telephone apparatus it has been necessary to develop frequency standards of even greater precision. For the Hawthorne plant of the Western Electric Co., the Bell Laboratories have recently developed new reference frequency equipment which is interesting as an embodiment of the most modern technique. This equipment provides frequencies, accurate to two parts in ten million, of $100,10,1 \cdot 0$ and $0.1 \mathrm{kc}$, which may be distributed as desired about the Hawthorne plant. It also includes apparatus to detect any errors in these frequencies, and in such cases to give an alarm if the error exceeds a certain very low value. Two independent reference frequency supplies are provided, which is advan- 